\title{
STRATEGIES OF MYTH-MAKING IN THE HISTORICAL AND PHILOSOPHICAL DISCOURSE OF THE NOVEL "THE WANDERING JEW" BY S. HEYM
}

\section{Ilinska N. I.}

\section{INTRODUCTION}

The idea that, "since the twentieth century, myth begins to occupy a privileged place in the culture, and mythological consciousness turns out to be a significant component of historical, ideological, and artistic consciousness", is the topos of modern. There is a huge number of literature works on the mythocentric trends of our time. The works devoted to the problems of the interaction of myth and literature, myth and history (P. Ricoeur, J.-F. Lyotard, R. Bart, J. Droysen, L. Hutchen, E. Wesseling, A. Compagnon, T. Bovsunivska, V. Malkina) are especially important for our research in the aspects of mythologization, myth-making and demythologization of literary texts. In the literature of the late $20^{\text {th }}$ and early $21^{\text {st }}$ centuries, these phenomena become links in one process, which is vividly presented in the novel "The Wandering Jew" (1981) by German writer Stefan Heym (1913-2001).

A few words about the title category of the work. The term "strategy", relevant to modern literary criticism, in the Penguin Dictionary of Literary Terms And Literary Theory is defined as "either an author's attitude towards his theme and subject, or his method or technique", Referring to the basic definition, we understand the strategies of myth-making as different ways of author's interpretation of a myth ("theme") and its artistic embodiment ("method or technique") in various parameters: from 1) using its structural and semantic elements without modification to organize the narration to 2) author's transformations of traditional mythologies for modeling a new artistic reality.

In our study, by discourse we mean verbal communication, the subject of which is views on a common problem: myth-making and historical fact

1 Хренов Н. А. От эпохи бессознательно мифотворчества к эпохе рефлексии о мифе // Миф и художественное сознание XX века /Ред. Н.А. Хренов; Гос.ин-т искусствознания. М.: Канон-плюс, 2011.С..79

2 The Penguin Dictionary of Literary Terms And Literary Theory / ed. J. Cuddon (revised by E. Preston). London: Penguin books, 1998. R. 276 
in the postmodern poetry of a literary text. The aim of our study is to consider myth-making strategies as genre-forming ones in the historical and philosophical discourse of the novel "The Wandering Jew" by Stefan Heym.

Actuality and degree of coverage of the problem. S. Heym's novel is insufficiently studied. Only several articles (G. Ishimbaeva, T. Vilisova, E. Boriseeva) and dissertations (N. Polishchuk, H-P. Ecker) are devoted to it. The analysis of literary sources allows us to identify scientific gaps, the filling of which determine the actuality and novelty of our work. We will analyze these sources from this point of view.

Thus, in the article "Historical novels "The King David Report", "The Wandering Jew" by Stefan Heym: of history and historical reflection" by T. Vilisova, the historical problems of the novel "The Wandering Jew" by Stefan Heym are considered. According to the author of the article, "the story in the novel is presented fragmentary: the creation of the Earth and man, the beginning of a new reckoning after the advent of Christ, his life and death, Germany after the Reformation, the $80-\mathrm{s}$ of the $20^{\text {th }}$ century in the GDR and Judgment day". The writer's attention is focused on showing the personality in the context of history, which allows the reader to personally recognize its movement. The issues of historical responsibility, which correlate with modern events in connection with changes in the axiological orientations of society, are especially acute. The article focuses on the functions of the mythological elements of the work, which form the semantic horizon of the novel and are the "key" to its understanding. According to the researcher, "the myth for S. Heym is a constant that allows to order dissimilar material (legend, religion, science) and organize it into a single text"3 Agreeing with this thesis, we emphasize that S. Heym's appeal to biblical history and apocrypha in the novel "The Wandering Jew" has primarily a metaphysical meaning. The writer creates an artistic reality in which a different mythopoetic picture of the world is presented. This aspect is noted by N.-P. Ecker who is the author of the dissertation on "The Wandering Jew". He believes that the history of mankind in S. Heym's novel is presented "as an episode of a more global structure - the cosmos". Indeed, the cosmism of the writer's worldview encompasses two key events in biblical history - the creation of the world

3 Вилисова Т. Исторические романы Стефана Гейма «Книга царя Давида», «Агасфер» : демифологизация истории и историческая рефлексия / https://philologicalstudies.org/dokumenti/2006/vol1/22.pdf

${ }^{4}$ Ecker H.-P. Poetisierung als Kritik. Stefan Heyms Neugestaltung der Erzählung vom Ewigen Juden. Tübingen: Narr, 1987 s. 91. 
and Armagedon. Apparently, from the point of view of Eternity, nontraditional assessments of character images - Jesus, Ahasuerus, Leuchtentrager (Lucifer), historical figures - Martin Luther, Philip Melanchthon, Paul von Eitzen, Lucas Cranach, were submitted by the myth-maker. One of the priority tasks of our study is to consider mythmaking strategies in the historical and philosophical line of the novel "The Wandering Jew" by Stefan Heym.

In E. Boriseeva's review article "The mythologem of Ahasuerus in the literature of post-modern epoch"5, S. Heym's novel is mentioned among others presented in the foreign literature of the $20^{\text {th }}$ and $21^{\text {st }}$ centuries. The author of the article sees the reason for the popularity of the migratory in the differentness and incompleteness of the of Ahasuerus in any culture, but the "eternal image" acquires a new life precisely in the dialogue of two consciousnesses - Us-Them. It has been rightly noted that in the process of transformation mythologem, the of Ahasuerus withdraws from pretext, the legendary image "acquires" new meanings, depending on contexts and author's intentions. Indeed, the image of the Eternal Wanderer in $\mathrm{S}$. Heym's novel is significantly different both from the legendary pretext and from the literary tradition. One of the further strategies of our research is to clarify the specifics of the secondary mythologization of the image of Ahasuerus in S. Heym's artistic consciousness.

In N. Polishchuk's dissertation "Transformation of Ahasuerus' mythologem in West European literature of the 19-20 centuries" image of the Wandering Jew is considered in a transhistorical context: from proto-text - the medieval legend of a man who insulted God, to the post-modern version of the mythologem of Ahasuerus in the novel by S. Heym. The author considers the ethno-specificity of this mythologem, comparing the invariant of the European legend about the Wandering Jew with the image of Marko Prokliatyi (Damned Marko) from the eponymously-named novel by O. Storozhenko (1806-1874). It has been marked the national component of the mythologem of Ahasuerus, that symbolizes "the scattering and foreignness of the Jews themselves around the world, which seems to be the realization of Ahasuerus' terrible curse on eternal".

5 Борисеева Е.А. Мифологема Агасфера в литературе эпохи постмодерна / http://elib.bsu. by/handle/123456789/36674

6 Поліщук Н. Трансформація міфологеми Агасвера в західноєвропейській літературі XIX - XX ст. Автореф. дис... канд. філол. наук: 10.01 .04 / Львів. нац. ун-т ім. I. Франка. - Л., 2001. 
Comparing the transformations of the mythologem of the Wandering Jew in the cultural and historical paradigms of the Romantic and postmodernism, N. Polishchuk identifies two models: the canonical paradigm of and the controversial paradigm of postmodernism. The dissertation examines the ambivalence and "diversity" of the post-modern version of Ahasuerus' mythologem. However, the use of "author's" terminology without necessary explanations, for example, the "polyapocryphal nature of Ahasuerus' mythologem", "the game aspect of the creation of meta-apocrypha" darkens the meaning of these interesting aspects of the study.

A study of literary sources devoted to S. Heym's novel "The Wandering Jew" allows us to determine and correct the vectors of our study.

\section{Multi-genre nature and myth-making: points of intersection}

As the analysis shows the genre structure of S. Heym's work "The Wandering Jew" in the context of author's myth-making is the least studied. And it is no coincidence, unsteady boundaries of the genre in nonclassical aesthetics give rise to thoughts of its disappearance (B. Croce, J. Derrida). To T. Bovsunivska's mind “... most researchers consider the category of the genre so old-fashioned that they do not use it at all, and the rest offer their own interpretation, which is so different from Aristotle's traditional times, that rather prevents the understanding and perception of a literary work than helps to clarify its artistic nature. The age of postmodernism shook the omnipotence of the genre" "7. In the literature of the $20^{\text {th }}$ century there are new forms of literary works that are characterized by genre diffusion (terminological synonyms - multi-genre nature, genre polyphony, genre shift, genre convergence).

Literary critics noticed the tendency of postmodern writers to decanonize and synthesize genres that is also observed in the novel "The Wandering Jew" by S. Heym. Mythologizing strategies, trends, complexes of dominant myths, processes of transformations and creations of new models, coupled with the dynamics of spiritual and aesthetic search, determine the multi-genre nature of S. Heym's novel "The Wandering Jew". Its multi-level structure covers the genre elements of a historicalphilosophical novel, a religious-historical novel, a myth / anti-myth novel, an apocryphal novel. The boundaries between these genre structures are

${ }^{7}$ Бовсунівська Т. В. Теорія літературних жанрів : Жанрова парадигма сучасного зарубіжного роману : Підручник / К.: Видавничо-поліграфічний центр «Київський університет», 2009. С. 64. 
easily pervious and open (S. Averintsev's term). The writer reinterprets the Sacred History, historical facts and personalities of German culture of the distant and recent past, referring to the concepts and poetics of postmodernism.

\section{Genre invariant of a historical novel in S. Heym's modification}

The genre dominant of S. Heym's novel "The Wandering Jew" is a historical and philosophical discourse, the specificity of which allows us to argue that the author created a new type of historical novel. To prove this, let us turn to the invariant model of the genre described by V. Malkina, a comparison with which will demonstrate the author's modifications from the point of view of the influence / not influence of the concepts and attitudes of postmodernism on it. In other words, it remains to be clarified what traditions of the historical novel S. Heym inherits, what is the essence of his innovations and how myth-making strategies are involved in the creation of a postmodern genre form of the historical novel.

According to V. Malkina, an invariant of a historical novel, i.e. a set of stable features and characteristics which are typical for the works of this genre, regardless of the time and place of their writing, includes such parameters. The main feature of the historical novel is the combination of historicism and "Gothic anthropologism". Among the many definitions of historicism, she accepts M.I. Steblin-Kamensky's "hypothesis of nonidentity". The essence of the hypothesis is "the assumption that the psychology of medieval man is not identical with the psychology of modern man. That is, historicism appears when the differences in human psychology are realized".

The following feature of the historical novel invariant can be traced in the speech (narrative) structure of the work. It implies "a combination of points of view of different eras" and "the presence of historical information" as a special compositional-speech form. At the level of the plot organization, the historical novel is characterized by adventurism, the ordeals of the hero, "the combination of the themes of "war and love", and all this against a background of a crisis historical era. The character system of the historical novel traces "the connection of fate and the position of the protagonist with a changing historical situation"; the presence of antagonist characters $^{8}$. We will consider these parameters in relation to S. Heym's novel "The Wandering Jew".

\footnotetext{
${ }^{8}$ Малкина В.Я. Поэтика исторического романа. Проблема инварианта и типология жанра: на материале русской литературы XIX - начала XX века : диссерт. канд. филол. наук. М. 2001. С. 108.
} 
We believe that in addition to understanding the differences in human psychology (according to Steblin-Kamensky), the concept of historical development, the philosophy of history by its author as a manifestation of historicism is an important component of the genre attribution of a historical novel ${ }^{9}$. There is every reason to state its presence in S. Heym's work. It is indisputable for a writer to believe that absolute truth is impossible, that truth consists of many subjective perceptions. He considers official and generally accepted history as a mythopoeic variant created as a result of information "filtering": what we know is only the tip of the iceberg ${ }^{10}$. It is obviously, that the basis of author's concept of history is post-modern understanding of it as a "big narrative" - history is what they write about it, and therefore it differs little from literature.

The crisis of confidence in meta-stories as a characteristic feature of postmodernism and its culture was first formulated in the work "Postmodernist destiny" ("La condition postmoderne") by J.-F. Lyotard. In Russian translation this work is known under the heading «Состояние постмодерна». According to the French philosopher, in a postmodern situation, the metanarratives have lost their "legitimizing" function of substantiation of the laws, moral norms and structures of social institutions ${ }^{11}$. Researchers argue that even non-configurational texts are not free from the subjective view of the historian and the appraisals inherent in modern times (см. об этом : П. Рикер, И. Дройзен) $)^{12}$. Doubts about the possibility of cognizing reality through historical knowledge and traditional philosophy give rise to "epistemological uncertainty". This state of man and society produces a need to look for other ways of comprehending being, which happens in the case of S. Heym. The writer's attempt to comprehend the movement of mankind in the "great time", in the context of relativity and distrust of explanatory systems, the desire to find support in universals continues the tradition of the German historical and mythological novel of T. Mann, G. Grass, K. Wolff.

It seems that in the historical and philosophical discourse of S. Heym's work, the specificity of the historicism of the post-modern novel is significantly manifested. On the one hand, the writer creates a purely

9 Соколянский М.Г. Историзм. Литературоведческие термины: Материалы к словарю. Коломна, 1999. С. 37-40.

10 Вилисова Т. Исторические романы Стефана Гейма «Книга царя Давида», «Агасфер»: демифологизация истории и историческая рефлексия / https://philologicalstudies.org/dokumenti/2006/vol1/22.pdf

${ }_{11}$ Лиотар Ж.-Ф. Состояние постмодерна. - Спб.: Алетейя, 1998. С. 7.

12 Дройзен, И. Г. Историка . СПб.: Владимир Даль, 2004. С.70, С.155 ; Рикёр, П. Время и рассказ. Т. 1 М., СПб.: Университетская книга, 1998. С. 204. 
historical novel, events in which can occur only in the described historical era - during the Reformation or democratic Germany, which determines the characters, actions and psychology of the heroes. On the other hand, the author appeals to the present and tests for strength, it would seem, unshakable truths and authorities, so that, to create his own myth based on universal mythological structures and personal experience of historical reality. Based on documented historical facts, the postmodern writer reserves the sacred right of the demiurge to freedom of interpretation and assessment of historical events and personalities, to rewrite historical myths and their characters.

The strategies of demythologization and "rewriting" of history are especially vividly shown in chapters devoted to Martin Luther (14831546), the German theologian who laid the foundation of the Protestant Reformation. Since he is not the protagonist of the work, this image remained almost unnoticed in a few publications devoted to the analysis of the novel. However, the debate about Luther and his teachings is latently present on the pages of the novel from beginning to end, making up his ideomyth based on the historical and philosophical reflection of the author. It seems that one of the mythological structures - the mythologem of the cultural hero - can serve as an interpretative model of the image of Martin Luther.

As it is known, the mythologem of the cultural hero embodies the ideas of harmony and order, which are consistently implemented in the movement from chaos to space. In modern culture, its semantics goes far beyond the boundaries of myth, encompassing the heroes of the epic, historical and religious figures. However, at the same time, the invariant basis is preserved - the activity of the cultural hero is assessed as constructive from the position of Eternity, on condition that it has a positive meaning for the regulation of being. It is quite natural that a personality of such a scale as M. Luther, who caused controversy during his lifetime, is surrounded by mythology in its historical existence. For the history of mankind, which exists as a metanarrative according to F. Lyotard, is not so important, if Luther actually nailed a poster to the church gate in Wittenberg or sent out his 95 theses as a document ${ }^{13}$; whether or not he threw an inkwell at the devil - all the more several places argue about their involvement in this event; during a storm or

${ }^{13}$ Brendler, G. Martin Luther. Theologie und Revolution. VEB Deutscher Verlag der Wissenschaften, Berlin, 1983. S. 107 
thunderstorm he took the oath of monasticism ${ }^{14}$ There is no doubt that we live in a world created by the Reformation. It is one of the starting points of the history of the Western world with all its successes and failures. In this regard, it is difficult to deny the importance of the personality of Martin Luther's activity, but we can tell about them, "breaking the reality from one or another point of view" 15 The choice of a way to tell a story is determined by the narrative perspective, which acts as a semantic correlate between the point of view and the narrated events ${ }^{16}$. S. Heym uses several narrative instances, both explicit and implicit in creating his own myth about M. Luther. The first two include the narratives of the schoolboy Paul von Eitzen - a supporter of Dr. Martinus and a professor from Jerusalem H. Leuchtentrager - his main exposer. An implicit instance is Ahasuerus' thoughts about the world order and free will, inviting the reader from this point of view to evaluate M. Luther's personality and his religious reform activity. It is the reader whom the author opens up a wide field of free choice in answer to the question: who was Martin Luther in history "a wheel that got into a rut" or "a coachman driving a bull"? This strategy of the author's relationship with the reader in S. Heym's new historical novel differs from the position of the omniscient author in the traditional one.

The historical storyline also tells about the life of Paul von Eitzen - a real younger contemporary of Martin Luther, a student to whom he patronized. The son of cloth and wool merchant Paul von Eitzen goes to Wittenberg to study theology under the supervision of M. Luther and F. Melanchthon. At the coaching inn, he meets Hans Leuchtentrager (the meaning of the German surname Leuchtentrager is identical to the semantics of Lucifer: light-carrying, light-bringer), which becomes his companion and adviser for life. Thanks to the help of Hans Leuchtentrager (i.e. Lucifer), the lazy, not bright, but ambitious Eitzen successfully passes the exams, receives a letter of recommendation from Luther, first becomes a pastor and then a bishop.

14 Kantzenbach, F.-W. Martin Luther. Der bürgerliche Reformator. Musterschmidt, Göttingen, 1972. S. 19

${ }_{15}^{15}$ Шмид В. Нарратология М.: Языки славянской культуры, 2003. С. 9.

16 Андреева В. А. Текстовые и дискурсные параметры литературного нарратива (на материале современной немецкоязычной прозы): дис. ... д. филол. наук СПб., 2009. C. 321-22; Viehöver, W. Erzählungen im Feld der Politik, Politik durch Erzählungen. Überlegungen zur Rolle der Narrationen in den politischen Wissenschaften. Politische Narrative. Konzepte - Analysen - Forschungspraxis. F. Gadinger, S. Jarzebski, T. Yildiz (eds.). Springer, Wiesbaden, 2014. S.82. 
The provocative convergence between Luther and Lucifer in their patronage of the theological career of blockhead Eitsen is a clearly unfriendly gesture of the writer towards the father of the Reformation, if not outright sarcasm. S. Heym emphasizes such traits of the theologians Luther and Melanchthon as vainglory, the desire to make an impression that allows the demon to manipulate them: «Er (Leuchtentrager) hat Luther und Melanchthon gut studiert, sie haben nichts miteinander zu reden, aber vor Publikum versuchen sie, einander $\mathrm{zu}$ übertreffen und werden $\mathrm{zu}$ solchen Chrysostomos, dass die Zuhörer vor Bewunderung ihre Münder öffnen» ${ }^{17}$.

It is significant that the main scenes in which Luther and Melanchthon are shown are given by the eyes of Paul von Eitzen, that is, the character originally apologetic for them. The author's irony manifests itself more clearly. It evaluates, for example, their everyday behavior. So, in the episode of the general meal, the sacred feast is clearly parodied: "In der Mitte des langen Tisches saß Dr. Martinus wie Jesus Christus beim letzten Abendmahl. Seinen großen Kopf auf die Faust stützend, schaute er sich träge die Tafelrunde an ${ }^{\text {" } 18}$. The image of the doctor is deliberately reduced: for the sake of a tasty piece of meat («Er nahm sich das saftigste Stück»), he stops the theological discussion. The compromising detail is "the expression of the eyes of Dr. Martinus is both critical and satisfied" at the sight of the "playful" Leuchtentrager artifact - a coral knife in the form of a naked female figure. The author notes with irony that the great theologian "did not recognize" the devil in one of the guests of his house.

The author fixed such a feature of $\mathrm{M}$. Luther as authoritarianism and rejection of a different opinion. During the discussion, he is often annoyed, and Paul is surprised to note his intolerance and the new outbursts of anger that accompany his speech. Nietzsche afterwards calls the "garrulity of anger" Luther's manner of stringing and piling charges against his enemies. This feature is also noted in historical sources, however, unlike $\mathrm{S}$. Heym, it is evaluated in the context of the psychology of the Middle Ages. "He was a product of his time," writes Dr. Benjamin Hasselhorn, curator of the exhibition about the great reformer at his house-museum in Wittenberg, "and Luther's times were loud and rude. At that time, the inhabitants of central Germany were not polite people". But there is also other evidence in favor of humanity, generosity and the hospitality of Luther, when fifty students, pilgrims, and colleagues sat at his table. It is

17 Heym S. Ahasfer . Fischer Taschenbuch Verlag. Frankfurt / M., 1992. / https://www.dieterwunderlich.de/Heym_Ahasver.htm

${ }^{18}$ Ibid 
narrated by Martin Luther's "Table Talks" ("Tischreden"), collected by his students. It is also known that four adopted children grew up in the theologian's house (except for six of his own, four of whom survived), and during the plague his house served as a hospital and hostel for students and staff. These widely known facts from Luther's biography could not be a secret for S. Heym, who grew up in German culture. The tendentious choice of historical facts, their artistic evaluation in an ironic and parody mode, through semantic inversion, testifies to the author's intention to demythologize the image of Martin Luther as a strategy for a new historical novel.

The image of Eitzen is the mirror that reflects the influence of the personality and statements of Dr. Luther on the average person. Their convergence especially closely occurs on the basis of anti-Semitism. The anti-Semitism of the doctor is shown in the total rejection of Jewry at the level of mentality and religion. So, when Melanchthon offers to hear the story of an eyewitness Ahasuerus about the torment of Christ in order to convert Jews to Christianity, the founder of the Reformation bursts out with an angry invective against the Jews: «Christianisieren! Rief der fromme Dr. Martinus aus. - Juden? Hören Sie auf meinen guten Rat: Erstens sollten alle ihre Synagogen und Schulen verbrannt, die Messbücher weggenommen, und der Glaubensunterricht der Talmudisten und Rabbiner verboten werden. Zweitens müssen junge und starke Juden mit Ketten, Äxten und Schaufeln versorgt werden, damit sie ins Schwitzen kommen, und wenn sie nicht wollen, müssen sie zusammen mit ihrem ewigen Juden aus unserem Land vertrieben werden; Sie alle haben gegen unseren Herrn Jesus Christus gesündigt, wofür sie verflucht sind, wie der Agaspher» ${ }^{19}$.

Using the method of intertextuality, S. Heym practically quotes a documentary source - seven advice-recommendations from the pamphlet of M. Luther "On the Jews and Their Lies" (Von den Juden und ihren Lügen, 1543), which he gives to the authorities on how to behave with the Jews. In the second part of the pamphlet, Luther for the first time brings forward against the Jews an argument not of the theological, but of an economic order. He accuses them of usury, greed, dishonesty and parasitism, which finds a sympathetic response in the petty soul of Paul von Eitzen. Listening to the doctor's eloquence, he fixes contradictions and double standards, discrepancies between his words and Christ's truth, which teaches us to love our enemies. However, in reality, getting a church

19 Heym S. Ahasfer. Fischer Taschenbuch Verlag. Frankfurt / M., 1992. / https://www.dieterwunderlich.de/Heym_Ahasver.htm 
pulpit is more dependent on Dr. Martinus, "kaum zu bezweifeln, dass er recht hat." In this way, S. Heym emphasizes the destructiveness of Luther's teachings and speeches, which undermine the moral principles of Christianity. It is worth noting the realization of such a stable feature of the structure of the historical novel as the presence of ethic conflict and moral issues.

Luther's anti-Semitism is a complex and painful problem not only for the Germans, but for Christianity as a whole. However, in S. Heym's novel, it covers the other sides of the versatile, of course, ambivalent personality of a genius German, who, according to Stefan Zweig, "is overwhelmed and swelled with power and violence of a whole nation." Luther's apologists prove that his anti-Semitism has a religious basis, being a manifestation of a traditional medieval worldview. That is really true, since he did not profess racial theories that form the basis of modern anti-Semitism. Nevertheless, the fact that the Nazis used the works and the name of Martin Luther to justify the Jewish pogroms, for example, on the so-called Kristallnacht (Novemberpogrome, 1938), is widely known. As it is known, any ideology is subject to mythologization. The appeal to M. Luther as the authority of the nation allowed the politicized elite to justify their inhuman actions, giving them legitimacy, to manipulate the mass consciousness to achieve ideological goals.

So, the analysis of S. Heym's novel "The Wandering Jew" demonstrates his author's doubts about the historical viability of M. Luther as a cultural hero who created or brought to people the fruits of civilization, taught them "norms of social life and sacred rituals" and "performed various feats of world order" the reformist activities of the professor of biblical theology at Wittenberg University, considering it to be destructive and disruptive by itself. It led to an all faith schism, and then to civil war and peasant riots (1524-1525) in Germany, which M. Luther condemned, calling for the murder of rebel peasants as "rabid dogs" ("Against the Murderous, Thieving Hordes of Peasants", 1525).

It is significant that in the novel "The Wandering Jew" the constant opponent of Dr. Martinus is Hans Leuchtentrager, an angel-deity who was cast out of heaven, secret adviser to the German princes, a professor from Jerusalem, and one of the participants in the intellectual discussion. The image of the fallen angel of Lucifer inherits the world literary tradition. As

${ }^{20}$ Мелетинский Е. Культурный герой // Мифы народов мира. Энциклопедия : в 2-х т. / гл. редактор С.А. Токарев. М. 1997. Т.2. С. 25. 
it befits the spirit of doubt, he is a great tempter and provocateur. He is smart, skeptical, insightful, not devoid of charm and attractiveness, despite the outward ugliness. "Part of the strength of one without a number / Doing good, wishing evil for everything», Leuchtentrager appears in the novel as a kind of arbiter of justice. The author trusts him with the ideological plan for assessing the spiritual and religious activities of Luther, which is another marker of the demythologization of the image of the latter. Observing the crushing of human nature as a reflection of the failure of the Higher Power («Was nützen all die Alexander die Großen oder Sokrates, wenn der Himmel jetzt nicht höher als die Zimmerdecke ist?»), he sarcastically takes notice of the doctor's reformism: «Zuerst gab er dem Papst einen Tritt, aber dann erkannte er, wie notwendig er war, die göttliche Weltordnung zu bewahren, damit das Oben oben und das Unten unten bleibt ${ }^{21}$. The postmodern writer plays paradoxes, offering characters unusual roles for them: the subverter and the spirit of evil to take care of the hierarchy and harmony of the divine universe, unlike the theologian, who destructs this world order.

It is significant that the defender of the "dark" side of Dr. Martinus's activities is advocated by the director of the Institute of Scientific Atheism, Professor Siegfried Baifus, as well as his curators from the special services and the Ministry of Education. They do not care and do not need historical truth, since there is an official point of view as a monopoly on truth. «Heute erinnert dich Herr Leuchtentrager an antisemitische Äußerungen und Schreiben Luthers und morgen zitiert er das Luther-Pamphlet aus der Zeit des Bauernkrieges gegen die "mörderischen und räuberischen Rotten der Bauern", die er aufforderte zu ,zerschmeißen, würgen, stechen, heimlich und öffentlich, wer da kann, wie man einen tollen Hund erschlagen muss", was nicht nur dich, sondern alle, die an der erfolgreichen Durchführung der geplanten Feierlichkeiten arbeiten, in eine unangenehme Lage bringt» ${ }^{22}$ - socialist leaders and inspirers remind the historian of his ideology S. Baifus. In a totalitarian state, scientific objectivity depends on the political moment and submits to ideology "history is being written." Consequently, on the eve of the 500th anniversary of M. Luther, Professor Leuchtentrager becomes an undesirable person due to his remark about the influence of the hero of the day on the birth of modern anti-Semitism. The so-called "discussion" is

21 Heym S. Ahasfer. Fischer Taschenbuch Verlag. Frankfurt / M., 1992. / https://www.dieterwunderlich.de/Heym_Ahasver.htm

22 Heym S. Ahasfer. Fischer Taschenbuch Verlag. Frankfurt / M., 1992. / https://www.dieterwunderlich.de/Heym_Ahasver.htm 
closed due to the presence of only one "correct" point of view, which is contained in the ideological myth of the great German approved by the authorities.

The mirror roll call of the episodes, which unites the two "disputes" occurring at different historical times, in medieval Alton and socialist Berlin, is interesting. Their subject is the problem of reality / symbolicalness of Ahasuerus - a man who offended Christ, a witness of His Calvary sufferings, and more broadly - the problem of the existence of God and the immortality of the soul. The comparison shows: times are different, but the result is the same - the one who has power has the "truth". The paradox is that in the first case, a career that gives the right to power and a comfortable existence is ensured by the glorification of God (Paul von Eitzen), and in the second, by his atheistic denial (S. Baifus and the socialist comrades). However, in either case, they fight against dissidence - the theologian against sectarian, Baifus against ideological, thereby ensuring a comfortable life.

To reveal the mechanisms of official "historical writing", S. Heym finds an original artistic solution. The epistolary discussion between H. Leuchtentrager and S. Baifus acts as an insert genre, compositionally localized in the structure of the work ${ }^{23}$ The correspondence also plays the role of "historical reference" as a special compositional and speech form, noted by V. Malkina as an invariant of the historical novel ${ }^{24}$. Here it is worth noting such a distinctive feature of S. Heym's historical novel, as a mixture of historical sources with legendary and mythological, the inclusion of hoaxes whose purpose is to verify their historical authenticity in the reality modeled by the author. An example is a detailed selection of national versions of the legend of Ahasuerus, a Report on the trial against the adviser of the emperor Julian the Apostate from the archives of the Great Port, Qumran scroll 9 Qres, etc. The postmodern principle of nonselection used by the author blurs the boundaries between real fact and fiction, stimulates the game with the reader, and creates an ironic mode of narration.

A comparison of the genre invariant of a historical novel with a postmodern one raises the question of S. Heym's modification of such a stable feature of a historical novel as a combination of historicism and "Gothic anthropologism". Researchers (V. Zhirmunsky, I. Nabytovich,

${ }^{23}$ Іванюк Б.П. Жанрологічний словник: Лірика. - Чернівці: Рута, 2001. С. 9.

24 Малкина В.Я. Поэтика исторического романа. Проблема инварианта и типология жанра: на материале русской литературы XIX - начала XX века : диссерт. канд. филол. наук. М. 2001. С. 108. 
T. Denisova, G. Zalomkina) noted the multi-level affinity between Gothic and myth in such parameters as a picture of the world, type of consciousness and understanding of reality, which finds expression in the semantics and poetics of the work. The cogency of the Gothic component in the historical and mythological structure of the novel is evidenced by the compositional role of Lucifer-Hans Leuchtentrager as a cross-cutting character that combines sacred and profane spheres, history and modernity. A special feature of the historical novel by S. Heym is the recoding of the motives and images of the Gothic novel in a postmodern manner to create an individual author's myth.

It is most obviously represented in the Gothic motive of the contract with the devil and his invariant - selling the soul in return for certain goods. In the "Dictionary of motives and plots", it is presented the motive structure of the contract with the devil, which includes the following elements: "the hero is in dire need (in love with an inaccessible woman / seeks to get rich / get promoted / become king, etc.) - seeks the path to the devil (a specific place, time, through an intermediary) - concludes an agreement / renounces Christ - receives what he wants - realizes his own fall - after repentance (possibly through a saint) he is saved" 25 . Let us compare the invariant structure of the motive with its modification in the postmodern historical novel.

S. Heym's transformation of this motive can be traced in several aspects. First of all, the key moment of the contract that is the sale of the soul to the devil is inverted. Leuchtentrager does not need it; he initially knows the value of the human race. A rebel who did not want to bow to God's creation evaluates the soul of Paul von Eitzen no more than the usual pastor's little soul, which «davon haben wir genug, und so eine Seele bekommt man am Markttag billiger als faulen Fisch» ${ }^{26}$. Then why does the demon need all this? Probably, for the sake of a game for which the process is more important than the result.

We will call one more difference from pretext, associated with the modification of the motive for renouncing Christ. In the novel "The Wandering Jew", the author portrays Eitzen as a kind of "medieval relativist". Having successfully passed the exam, candidate Eitzen, «demnächst Magister, hat nicht vergessen, wem er alles schuldete: erstens

${ }^{25}$ Словарь-указатель сюжетов и мотивов русской литературы. Экспериментальное издание / Отв. ред. Е. К. Ромодановская. Новосибирск: Изд-во СО РАН, 2003. Вып. 1. Ред.: М. А. Бологова, Е. К. Никанорова, Е. Н. Проскурина. С. 87.

26 Heym S. Ahasfer. Fischer Taschenbuch Verlag. Frankfurt / M., 1992. / https://www.dieterwunderlich.de/Heym_Ahasver.htm 
natürlich dem Gott, von dem alle Gnade kommt, und zweitens und nicht weniger seinem Freund Leuchtentrager ${ }^{27}$. Accepting the help of the devil, he does not even think to deny the Savior. Both God and the devil safely "coexist" in his wretched little soul, because they perform the same functions - they help "to get rich / get promotion".

Moreover, because of his lack of spirituality, he does not realize the depth of the fall and does not consider himself an apostate. The doctor of theology, Eitzen, does not know the feeling of remorse. When he nevertheless has the urge to pay the bills and Ahasuerus reads him a line from the Old Testament about the punishment of evil and hypocritical shepherds, the bishop tries to save himself from the infernal flame by word juggling. Habitually resorting to a set of quotes from the Bible, he claims that «menschliche Sünden auf Gott liegen» ${ }^{28}$. However, Eitzen immediately puts himself into a trap, because in the sermons on the Divine Providence he wrote differently: «Der Fluch für den Gottlosen ist von ihm selbst vorgegeben ${ }^{29}$. The scene of "minor eschatology" was solved in a gaming way - the abduction of the soul of Eitzen, who is more frightened by the prospect of being stuck in a pipe than the flight with infernal forces.

The transformation covers other Gothic motives in S. Heym's novel. For example, the motive of a villain whose image is devoid of characteristic demonization; the motive of the dead bride, embodied in the image of Margret - the devilish spawn of rags; the motive of the birth curse - the birth of Margarita, the youngest, hunchbacked and lame, who was especially loved by her mother for known reasons.

\section{CONCLUSIONS}

Thus, in the historical and philosophical discourse of the novel "The Wandering Jew" by S. Heym, a writer of a nonconformist constitution and an opponent of any ideologies, once again denies the existence of a "right" point of view that has been unified for all times, no matter how authoritative it may seem. Turning to the documents of the era, historical facts, pamphlets and texts of the teachings of M. Luther, mythological and legendary material, using the strategies of demythologization and the techniques of postmodern poetics, the author creates his own ideological myth about the theorist-reformer. Moreover, "the data for the historical interpretation are not the realities that have not disappeared, but their trace

27 Heym S. Ahasfer . Fischer Taschenbuch Verlag. Frankfurt / M., 1992. / https://www.dieterwunderlich.de/Heym_Ahasver.htm

${ }^{28}$ Ibid

${ }^{29}$ Ibid 
in the present" ${ }^{\prime 30}$. By demythologizing the story and destroying its power status, S. Heym uses various game strategies inherent in postmodern poetics: total irony, parody, pastiche, semantic inversion, intertextuality, playing with the reader, images, game element in the narrative structures of the novel, convergence of spatial and temporal coordinates of different eras. Relying on tradition and modifying the genre forms of a historical novel, S. Heym creates his new type that is a postmodern historical novel.

\section{SUMMARY}

The article deals with the strategies of myth-making in the historical and philosophical discourse of the novel "The Wandering Jew" by S. Heym. The concepts of "myth-making strategies", "discourse", and "multi-genre nature" are being clarified. Genre modifications of the historical novel by S. Heym through its comparison with the genre invariant of the traditional historical novel have been revealed. The author's transformations of the principle of historicism, "Gothic anthropologism", the myth-making strategies in the interpretation of history have been ascertained. The historical images of Martin Luther and Paul von Eitzen, the postmodern poetics of their artistic realization have been characterized. It is proved that the main myth-making strategy is the demythologization of history as a discourse of power. The features of the genre structure of S. Heym's novel "The Wandering Jew" as a postmodern historical novel have been described.

\section{REFERENCES}

1. Андреева В. А. Текстовые и дискурсные параметры литературного нарратива (на материале современной немецкоязычной прозы): дис. ... д. филол. наук СПб., 2009. 361 с.

2. Бовсунівська Т. В. Теорія літературних жанрів : Жанрова парадигма сучасного зарубіжного роману : Підручник / К.: Видавничополіграфічний центр «Київський університет», 2009. 519 с.

3. Борисеева Е. А. Мифологема Агасфера в литературе эпохи постмодерна / http://elib.bsu. by/handle/123456789/36674

4. Вилисова Т. Исторические романы Стефана Гейма «Книга царя Давида», «Агасфер» : демифологизация истории и историческая рефлексия / https://philologicalstudies.org/dokumenti/2006/vol1/22.pdf

30 Колодинская Е.В. Историческое прошлое как предмет высказывания: современная англоязычная проза и постмодернистская историография (Г. Свифт, Дж. Барнс): Дисс. .канд. филол. наук. М., 2004. 139 с. 
5. Гейм С. Агасфер / https://bookscafe.net/book/geyms_stefanagasfer-184183.html

6. Дройзен И. Г. Историка . СПб.: Владимир Даль, 2004. 584 с.

7. Ишимбаева Г. Г. Трансформация библейского мифа в литературе постмодернизма («Агасфер» Стефана Гейма) // www.lib.csu.ru/vch/2/1997_01/019.pdf

8. Іванюк Б. П. Жанрологічний словник: Лірика. Чернівці: Рута, $2001.92 \mathrm{c}$.

9. Колодинская Е. В. Историческое прошлое как предмет высказывания: современная англоязычная проза и постмодернистская историография (Г. Свифт, Дж. Барнс): Дисс. ... канд. филол. наук. М., 2004. 139 c.

10. Лиотар Ж.-Ф. Состояние постмодерна. - Спб.: Алетейя, 1998. $160 \mathrm{c}$.

11. Малкина В. Я. Поэтика исторического романа. Проблема инварианта и типология жанра: на материале русской литературы XIX - начала XX века : дис... канд. филол. наук. М. 2001. 216 с.

12. Мелетинский Е. Культурный герой // Мифы народов мира. Энциклопедия : в 2-х т. / гл. редактор С.А. Токарев. М. 1997. Т. 2. C. 25-27.

13. Нямцу А. Е. «Бессмертный странник в человеческом мире» / К проблеме литературного функционирования легенды об Агасфере в контексте христианской аксиологии». Легендарные образы в литературе. Черновцы: «Рута», 2002. С. 127-164

14. Поліщук Н. Трансформація міфологеми Агасвера в західноєвропейській літературі XIX - XX ст. Автореф. дис... канд. філол. наук: 10.01.04 / Львів. нац. ун-т ім. І. Франка. - Л., 2001. - 20 с.

15. Рикёр П. Время и рассказ. Т. 1 М., СПб.: Университетская книга, 1998. 313 с.

16. Словарь-указатель сюжетов и мотивов русской литературы. Экспериментальное издание / Отв. ред. Е. К. Ромодановская. Новосибирск: Изд-во СО РАН, 2003. Вып. 1. Ред.: М. А. Бологова, Е. К. Никанорова, Е. Н. Проскурина. 243 с.

17. Соколянский М. Г. Историзм. Литературоведческие термины: Материалы к словарю. Коломна, 1999. С. 37-40.

18. Хренов Н. А. От эпохи бессознательно мифотворчества к эпохе рефлексии о мифе // Миф и художественное сознание XX века / Ред. Н.А. Хренов; Гос.ин-т искусствознания. М.: Канон-плюс, 2011. C. $11-82$.

19. Шмид В. Нарратология . М.: Языки славянской культуры, 2003. 312 c. 
20. The Penguin Dictionary of Literary Terms And Literary Theory / ed. J. Cuddon (revised by E. Preston). London: Penguin books, 1998. R. 276.

21. Brendler G. Martin Luther. Theologie und Revolution. VEB Deutscher Verlag der Wissenschaften, Berlin, 1983. $452 \mathrm{~s}$.

Heym S. Ahasfer . Fischer Taschenbuch Verlag. Frankfurt / M., 1992.244s./ https://www.dieterwunderlich.de/Heym_Ahasver.htm

22. Ecker H.-P. Poetisierung als Kritik. Stefan Heyms Neugestaltung der Erzählung vom Ewigen Juden. Tübingen: Narr, 1987 (Beiträge zur Sprach- und Literaturwissenschaft. Bd. 13)

23. Kantzenbach F.-W. Martin Luther. Der bürgerliche Reformator. Musterschmidt, Göttingen, 1972. 104 s.

24. The Penguin Dictionary of Literary Terms and Literary Theory / ed. J. Cuddon (revised by E. Preston). London: Penguin books, 1998. R. 276

25. Viehöver W. Erzählungen im Feld der Politik, Politik durch Erzählungen. Überlegungen zur Rolle der Narrationen in den politischen Wissenschaften. Politische Narrative. Konzepte - Analysen Forschungspraxis. F. Gadinger, S. Jarzebski, T. Yildiz (eds.). Springer, Wiesbaden, 2014. Pp. 67-91.

Information about the author: Ilinska N. I.

Doctor of Philology, Professor, Head of the Department of World Literature and Culture named after professor O. Mishukov, Kherson State University 40 rokiv Zhovtnya str., Kherson, 73000, Ukraine 